Article

\title{
Dietary Supplement of Large Yellow Tea Ameliorates Metabolic Syndrome and Attenuates Hepatic Steatosis in $\mathrm{db} / \mathrm{db}$ Mice
}

\author{
Yun Teng ${ }^{\dagger}$, Daxiang $\mathrm{Li}^{\dagger}{ }^{\dagger}$, Ponmari Guruvaiah, Na Xu and Zhongwen Xie * \\ State Key Laboratory of Tea Plant Biology and Utilization, School of Tea and Food Sciences and Technology, \\ Anhui Agricultural University, Hefei 230036, China; tengyunyy@sina.cn (Y.T.); dxli@ahau.edu.cn (D.L.); \\ Ponmariguruvaiah@yahoo.com (P.G.); naxu2014@ahau.edu.cn (N.X.) \\ * Correspondence: zhongwenxie@ahau.edu.cn; Tel.: +86-551-65786153 \\ t These authors contributed equally to this work.
}

Received: 1 December 2017; Accepted: 9 January 2018; Published: 12 January 2018

\begin{abstract}
Yellow tea has been widely recognized for its health benefits. However, its effects and mechanism are largely unknown. The current study investigated the mechanism of dietary supplements of large yellow tea and its effects on metabolic syndrome and the hepatic steatosis in male $\mathrm{db} / \mathrm{db}$ mice. Our data showed that dietary supplements of large yellow tea and water extract significantly reduced water intake and food consumption, lowered the serum total and low-density lipoprotein cholesterol and triglyceride levels, and significantly reduced blood glucose level and increased glucose tolerance in $\mathrm{db} / \mathrm{db}$ mice when compared to untreated $\mathrm{db} / \mathrm{db}$ mice. In addition, the dietary supplement of large yellow tea prevented the fatty liver formation and restored the normal hepatic structure of $\mathrm{db} / \mathrm{db}$ mice. Furthermore, the dietary supplement of large yellow tea obviously reduced the lipid synthesis related to gene fatty acid synthase, the sterol regulatory element-binding transcription factor 1 and acetyl-CoA carboxylase $\alpha$, as well as fatty acid synthase and sterol response element-binding protein 1 expression, while the lipid catabolic genes were not altered in the liver of $\mathrm{db} / \mathrm{db}$ mice. This study substantiated that the dietary supplement of large yellow tea has potential as a food additive for ameliorating type 2 diabetes-associated symptoms.
\end{abstract}

Keywords: large yellow tea; db/db mice; hepatic steatosis; metabolic syndrome; mechanism

\section{Introduction}

Metabolic syndrome is a group of the most dangerous risk factors associated with type 2 diabetes and cardiovascular disease (CVD) [1-9]. According to the joint statement from the International Diabetes Federation (IDF), the American Heart Association (AHA)/National Heart, the Lung and Blood Institute (NHLBI), the World Heart Federation, the International Atherosclerosis Society, and the International Association for the Study of Obesity, a person defined as having metabolic syndrome must have three or more of the following risk factors: obesity, high plasma TG level $(\geq 1.7 \mathrm{mmol} / \mathrm{L}$ ), high blood pressure (systolic blood pressure $\geq 130 \mathrm{mmHg}$ or diastolic blood pressure $\geq 85 \mathrm{mmHg}$ ), high fasting plasma glucose $(\geq 5.6 \mathrm{mmol} / \mathrm{L})$, and reduced HDL cholesterol $(<1.0 \mathrm{mmol} / \mathrm{L}$ in males, $<1.3 \mathrm{mmol} / \mathrm{L}$ in females) $[3,10,11]$. Right now, there are approximately a quarter of adults suffering from metabolic syndrome, and obesity is the primary and direct cause of metabolic syndrome and type 2 diabetes [11,12]. Type 2 diabetes (T2D) is a long-term metabolic disorder that is characterized by high blood glucose and insulin resistance. Diabetic complications include retinopathy, hypertension, cardiovascular diseases, kidney failure, and even ketoacidosis [5]. The $\mathrm{db} / \mathrm{db}$ mouse is a leptin receptor mutant mouse model that is widely used for the study of T2D and metabolic syndrome [13]. The phenotypes and pathogenesis of T2D in $\mathrm{db} / \mathrm{db}$ mice are similar to those of human 
T2D mellitus $[13,14]$. The mutation mice show hyperphagia due to defects in leptin signaling, leading to obesity, hyperinsulinemia, insulin resistance, dyslipidemia, hyperglycemia, and inflammation at the age of 3-4 months [13-15].

Based on various manufacturing processes and the degrees of fermentation, tea-one of the three most popular beverages worldwide-is classified into six main categories: non-fermented green tea, slightly-fermented white tea, partly-fermented yellow tea, semi-fermented oolong tea, fully-fermented black tea, and post-fermented dark tea [16]. At present, in addition to exploring effective drug therapy, increasing attention has been paid to the use of tea as a supplementary treatment for metabolic syndrome [17-20]. Some reports have suggested that the green tea extract can significantly reduce body weight gain, decrease body mass index (BMI) and levels of total cholesterol (TC), triglyceride (TG), and low-density lipoprotein (LDL) cholesterol, and increase energy expenditure and satiety at mealtime on obese patients [18,19]. Moreover, Kang et al. [20] found that fermented green tea, compared with green tea, had better anti-obesity, hypoglycemic, hypolipidemic, and antioxidant effects in $\mathrm{db} / \mathrm{db}$ mice and made the mice more resistant to type 2 diabetes. The researchers also focused on the regulation and effect of glucose and lipid metabolism with an epigallocatechin-3-gallate (EGCG), a secondary metabolite of tea. Ortsäter et al. [21] reported that, in db/db mice, EGCG reduced the pathological changes of islets and increased the number and size of islet cells, thus accordingly improving the function of pancreatic secretion, which helped to delay the course of metabolic syndrome. However, it has been proven that high doses of EGCG produced cytotoxicity and hepatotoxicity, which indicates that crude extracts might be safer than a single substance [22-25].

Large yellow tea, made from "one bud 6 leaves" of tea plant (Camellia sinensis), is one of the most famous traditional yellow teas in China, which is very popular because of its unique burnt flavor. A recent study from the Institute of Cancer Research (ICR) proved that yellow tea had a significant anti-hyperglycemic effect in high-fat-diet-induced mice when compared with green tea, black tea, and dark tea, which confirmed that yellow tea had a certain role in the recovery of glucose metabolism disorder [22]. However, high-fat-diet-induced ICR mice are not typical diabetic mice, and there is a lack of long-term experiments investigating the effect of yellow tea on rodent models of metabolic syndrome. Therefore, the current study comparatively investigated the molecular mechanism of dietary supplements of large yellow tea powder and its crude water extracts and their effects on glucose and lipid metabolism as well as the hepatic steatosis of middle-age $\mathrm{db} / \mathrm{db}$ mice over a 10 week treatment period.

\section{Results}

2.1. Quantitative Analysis of Characteristic Components in Large Yellow Tea and Its Water Extract by High Pressure Liquid Chromatography LYT and LWE by HPLC

The chromatographic pattern obtained from quantitative high-pressure liquid chromatography (HPLC) analysis of large yellow tea and its water extract were compared with standards representing epigallocatechin (EGC), catechin (C), epicatechin (EC), (-)-epigallocatechin-3-gallate (EGCG), (-)-gallocatechin-3-gallate (GCG), (-)-epicatechin-3-gallate (ECG), theanine, and caffeine. The results are listed in Table 1.

The quantitative analysis showed that ECGC was a major constituent identified in both LYT and LWT. The concentration of EGCG in LYT and LWT was $4.250 \pm 0.023 \mathrm{mg} / \mathrm{g}$ and $13.774 \pm 0.543 \mathrm{mg} / \mathrm{g}$, respectively, which produced an almost equal concentration of EGCG in both the 5\% large yellow tea and $1.5 \%$ water extract diets used to feed $\mathrm{db} / \mathrm{db}$ mice. Along with higher levels of caffeine and theanine, LWE saw a remarkable amount of total catechins when compared with that in LYT $(27.910 \pm 0.011$ vs. $11.531 \pm 0.035 \mathrm{mg} / \mathrm{g})$. 
Table 1. Quantitative data for catechins, caffeine, and theanine in large yellow tea (LYT) and its water extract (LWE) via HPLC analysis.

\begin{tabular}{|c|c|c|c|c|c|c|c|c|}
\hline & Caffeine & EGC & $\mathrm{C}$ & EC & EGCG & GCG & ECG & Theanine \\
\hline LWE (mg/g) & $18.766 \pm 0.394$ & $1.133 \pm 0.464$ & $0.536 \pm 0.096$ & $1.231 \pm 0.045$ & $13.774 \pm 0.543$ & $2.970 \pm 0.107$ & $4.117 \pm 0.145$ & $7.625 \pm 1.257$ \\
\hline LYT (mg/g) & $8.906 \pm 0.282 * *$ & $0.731 \pm 0.003^{* * *}$ & $0.184 \pm 0.002 *$ & $0.811 \pm 0.002^{* * *}$ & $4.250 \pm 0.023^{* * *}$ & $0.877 \pm 0.002^{* * *}$ & $1.237 \pm 0.004^{* * *}$ & $0.648 \pm 0.166^{* * *}$ \\
\hline
\end{tabular}




\subsection{Effect of LYT and LWE on Diabetic Syndrome on $d b / d b$ Mice}

T2D mellitus is characterized by increased eating and drinking as well as late-stage weight loss [5,12-14]. We measured food consumption and water intake of control and $\mathrm{db} / \mathrm{db}$ mice with different dietary treatments in order to figure out the effect of large yellow tea and its water extract on phenotypes in $\mathrm{db} / \mathrm{db}$ mice. The food consumption and water intake in the $\mathrm{db} / \mathrm{db}$ mice were significantly increased when compared with the control mice at 10 weeks old (Figure 1A,D). After four weeks of tea dietary supplement (14 weeks old), db/db + LYT, and db/db + LWE group mice showed a dramatic decrease in both food consumption and water intake when compared with $\mathrm{db} / \mathrm{db}+\mathrm{SC}$ mice (Figure 1B,E). Furthermore, this decrease in food consumption and water intake was persistently observed throughout the experimental period (20 weeks old) (Figure 1C,F). However, there was no difference in food consumption and water intake between the $\mathrm{C}+\mathrm{SC}$ group and $\mathrm{C}+\mathrm{LYT}$ group mice (Figure 1A-F). Interestingly, we found that the $\mathrm{db} / \mathrm{db}$ mice fed LYT had a more profound effect on the reduction of water intake than that of $\mathrm{db} / \mathrm{db}$ mice fed with the LWE diet (Figure 1E,F).
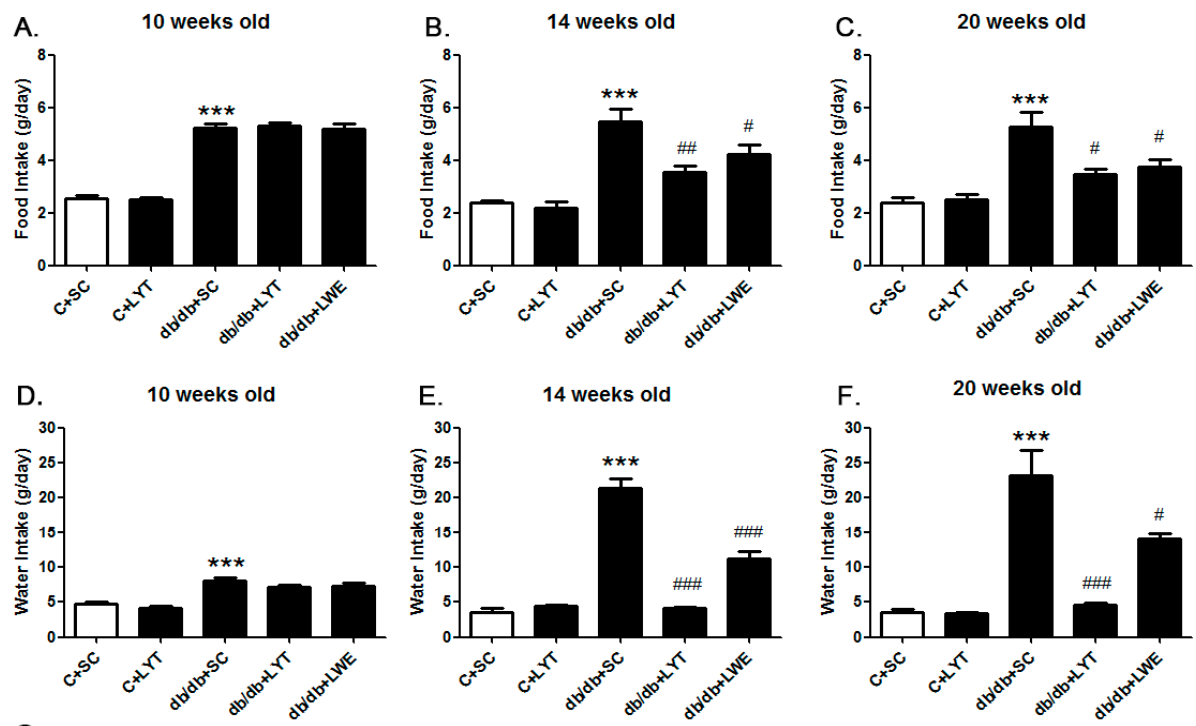

G.

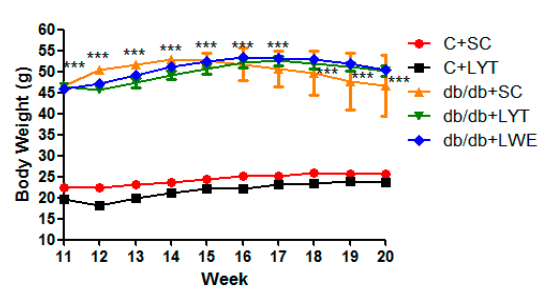

Figure 1. Food consumption (A-C) water intake (D-F) and body weight $(\mathbf{G})$ of the control and $\mathrm{db} / \mathrm{db}$ mice. C + SC: control mice fed the standard AIN93 diet (SC); C + LYT: control mice fed SC containing $5 \%$ of the large yellow tea powder (LYT); db/db $+\mathrm{SC}: \mathrm{db} / \mathrm{db}$ mice fed SC diet; $\mathrm{db} / \mathrm{db}+\mathrm{LYT}$ : $\mathrm{db} / \mathrm{db}$ mice fed LYT diet; $\mathrm{db} / \mathrm{db}+$ LWE: $\mathrm{db} / \mathrm{db}$ mice fed LWE diet. Values are means $\pm \mathrm{SE}(n=3)$. *** $p<0.001$ when compared with the $\mathrm{C}+\mathrm{SC}$ group; $\# p<0.05 ; \# \# p<0.01$; \#\#\# $p<0.001$ when compared with the $\mathrm{db} / \mathrm{db}+\mathrm{SC}$ group.

Moreover, we observed the body weights of the control and $\mathrm{db} / \mathrm{db}$ mice 10-20 weeks old fed various diets (Figure 1G). In the control groups, the body weights of the mice fed an AIN 93 standard diet $(C+S C)$ or an AIN 93 diet containing 5\% large yellow tea powder $(C+$ LYT $)$ were increased slightly from 11 to 20 weeks. There was no difference in body weight gain between the two groups. However, the $\mathrm{db} / \mathrm{db}$ mice fed with SC showed remarkable obesity, and the body weights were significantly higher than the body weights of the control mice throughout the experimental period 
$(p<0.001)$. The T2D mouse model has phenotypes of obesity and emaciation in later stages due to diabetic complications $[14,26]$. In our study, the body weights of $\mathrm{db} / \mathrm{db}$ mice fed an AIN 93 diet $(\mathrm{db} / \mathrm{db}+\mathrm{SC})$ gradually increased from 11 to 14 weeks old and then consistently decreased from 14 to 20 weeks old due to the development of diabetic complications. However, the body weights of both the $\mathrm{db} / \mathrm{db}+$ LWE group and the $\mathrm{db} / \mathrm{db}+$ LYT group increased gradually from 10 to 16 weeks old and then decreased slowly until 20 weeks old (Figure 1G).

\subsection{Protective Effect of LYT and LWE on Serum Lipids Profile of $d b / d b$ Mice}

Our data showed that the level of TG, LDL-C, and TC was significantly increased in $\mathrm{db} / \mathrm{db}+\mathrm{SC}$ mice than those in the control mice fed a chow diet (Figure $2 \mathrm{~A}-\mathrm{C}$ ). The $\mathrm{db} / \mathrm{db}$ mice fed a diet containing LYT and LWE showed greater reductions in the level of TG, LDL-C, and TC when compared with that of the $\mathrm{db} / \mathrm{db}$ mice fed a standard chow diet. Interestingly, after 10 weeks of dietary supplement, the levels of TG, LDL-C, and TC in the $\mathrm{db} / \mathrm{db}+\mathrm{LYT}$ and $\mathrm{db} / \mathrm{db}+\mathrm{LWE}$ group mice were close to the levels in the control mice fed a standard chow diet. However, the tea dietary supplement did not alter the concentration of HDL-C (Figure 2D).

A.

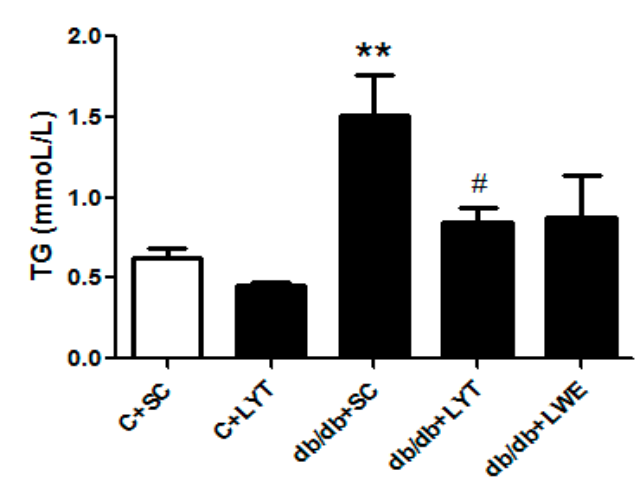

C.

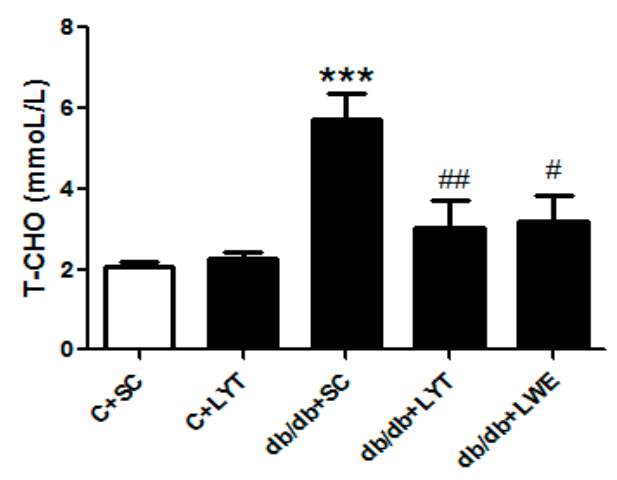

B.

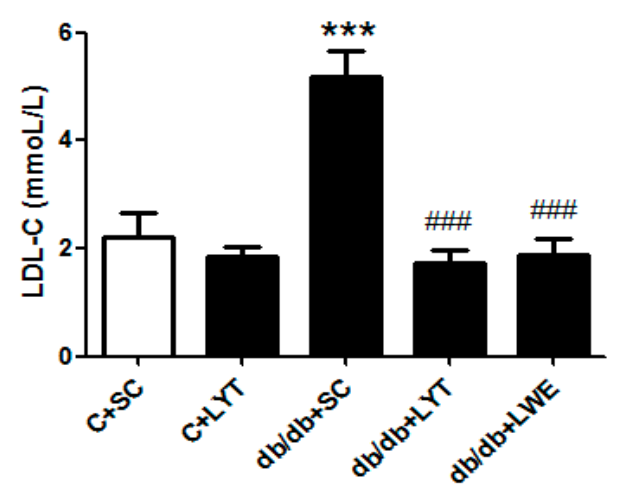

D.

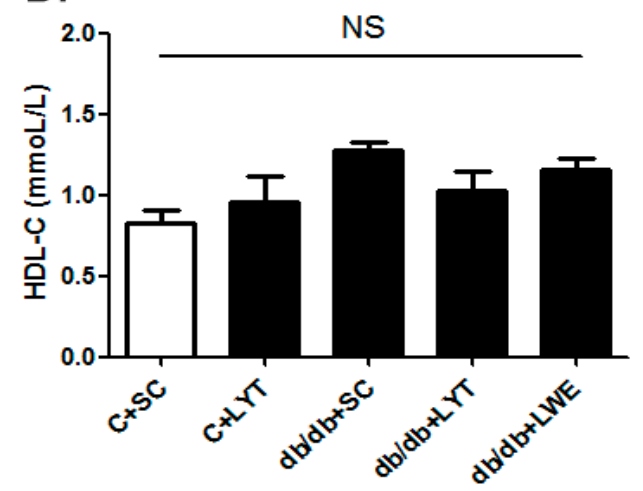

Figure 2. Serum lipid profile of six groups of mice at 20 weeks old. Triglyceride (A); low-density lipoprotein cholesterol (B); total cholesterol (C); and high-density lipoprotein cholesterol (D). Values are means \pm SE $(n=4-6) .{ }^{* *} p<0.01$; ${ }^{* * *} p<0.001$ compared with $\mathrm{C}+\mathrm{SC}$ group; $\#<0.05$; \#\# $p<0.01$; $\# \#$ $p<0.001$ when compared with the $\mathrm{db} / \mathrm{db}+\mathrm{SC}$ group; NS, no significant difference.

\subsection{LYT Reduced the Blood Glucose and Improved Glucose Tolerance in db/db Mice}

Hyperglycemia and glucose intolerance are major indicators of T2D mellitus $[5,13,27]$. Accordingly, we dynamically measured blood glucose during the entire experimental period. The data showed that fasting blood glucose levels were significantly elevated in $\mathrm{db} / \mathrm{db}$ mice fed a standard chow diet compared to the control mice from 10 to 20 weeks old. In addition, the $\mathrm{db} / \mathrm{db}$ mice were 
prone to becoming diabetic at the age of 11 weeks, with glucose levels over $300 \mathrm{mg} / \mathrm{dL}$ (Figure 3A). Additionally, the $\mathrm{db} / \mathrm{db}$ mice fed a standard chow diet showed gradually increased blood glucose levels from 300 to approximately $500 \mathrm{mg} / \mathrm{dL}$ from 11 to 20 weeks old. Surprisingly, the blood glucose level of $\mathrm{db} / \mathrm{db}$ mice fed with LYT for 2 weeks was significantly decreased. After four weeks of dietary supplement with LYT, the blood glucose level in the $\mathrm{db} / \mathrm{db}+$ LYT mice decreased to the level almost equal to the level of control mice. Furthermore, the blood glucose level of the $\mathrm{db} / \mathrm{db}+\mathrm{LYT}$ group mice remained pretty low until 20 weeks old. In contrast, the $\mathrm{db} / \mathrm{db}$ mice fed with $\mathrm{LWE}$ showed a greater reduction in blood glucose level during the first four weeks (12 to 16 weeks old) of treatment and then stayed at a high level (around $300 \mathrm{mg} / \mathrm{dL}$ ) until 20 weeks old. These data suggest that the LYT dietary supplement had a better effect on reducing blood glucose levels than did the LWE dietary supplement in middle-age $\mathrm{db} / \mathrm{db}$ mice.

A.

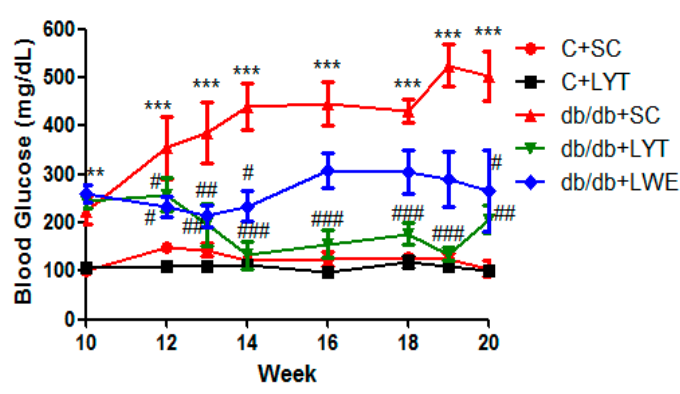

B.

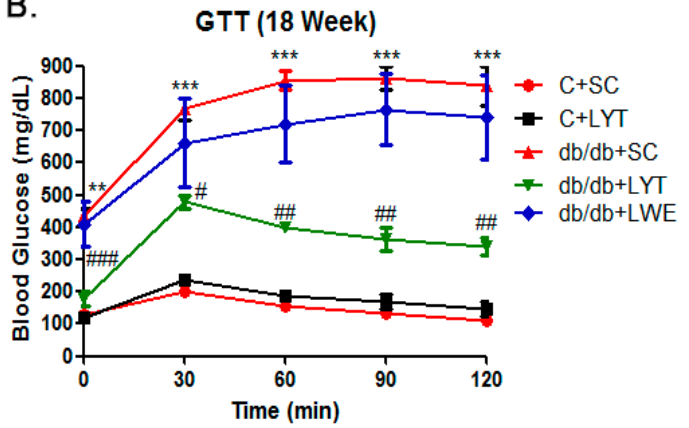

Figure 3. Blood glucose (A) and glucose tolerance test (B) in five group of mice. Values are means $\pm \mathrm{SE}$ $(n=4-6) .{ }^{* *} p<0.01 ;{ }^{* *} p<0.001$ when compared with the C + SC group; \# $p<0.05 ; \# \#<0.01$; \#\#\# $p<0.001$ when compared with the $\mathrm{db} / \mathrm{db}+\mathrm{SC}$ group.

The glucose tolerance test (GTT) showed no significant difference between $\mathrm{db} / \mathrm{db}+\mathrm{SC}$ and the $\mathrm{db} / \mathrm{db}+$ LWE mice at 18 weeks old (Figure 3B). However, db/db + LYT mice efficiently catabolized the blood glucose, despite failing to restore near normal values after $120 \mathrm{~min}$ of glucose injection (Figure 3B). We found that LYT had a better effect on raising glucose tolerance than did LWE in $\mathrm{db} / \mathrm{db}$ mice at the age of 18 weeks

\subsection{LYT and LWE Attenuate Hepatic Steatosis in db/db Mice}

The liver weight to body weight ratio is an important index for fatty liver. Our data showed that the liver weight to body weight ratio in $\mathrm{db} / \mathrm{db}$ mice fed a chow diet was significantly higher than that of the control mice fed a chow diet. Additionally, the $\mathrm{db} / \mathrm{db}+\mathrm{LYT}$ and $\mathrm{db} / \mathrm{db}+\mathrm{LWE}$ group mice showed a significantly decreased liver-to-body weight ratio when compared with that of the $\mathrm{db} / \mathrm{db}$ mice fed a chow diet (Figure $4 \mathrm{C}$ ). Furthermore, this index in the $\mathrm{db} / \mathrm{db}+\mathrm{LYT}$ mice was lower than that in the $\mathrm{db} / \mathrm{db}+$ LWE mice, suggesting that LYT had a better effect on preventing fatty liver formation than LWE.

To better understand the protective effect of LYT and LWE on liver tissue structure in the five groups of mice, we examined the hepatic histology (Figure 4A). After 10 weeks of feeding with LYT, there was no difference in hepatic lobules between the C + SC and C + LYT mice. However, we found that the $\mathrm{db} / \mathrm{db}$ mice with a standard chow diet had severe nonalcoholic fatty liver cells. Obviously, we observed diffuse hepatic fatty infiltration and amyloidosis in liver tissues, which caused a disruption in the structure of hepatic lobules in $\mathrm{db} / \mathrm{db}$ mice fed a standard chow diet. In $\mathrm{db} / \mathrm{db}$ mice fed with LYT and LWE diets, the liver tissues had smaller areas of fatty infiltration in liver cells, and the structure of hepatic lobules was integral. We also calculated the ratio of normal liver cells to total hepatic cells in the visual fields. We observed that $\mathrm{db} / \mathrm{db}$ mice fed with LYT and LWE diets showed more normal liver cells than those of $\mathrm{db} / \mathrm{db}$ mice fed a standard chow diet (Figure $4 \mathrm{~B}$ ). Again, the $\mathrm{db} / \mathrm{db}$ mice fed 
with LYT showed more profoundly influenced the attenuation of hepatic steatosis when compared to the $\mathrm{db} / \mathrm{db}$ mice fed with LWE.

A.

$\mathrm{C}+\mathrm{SC}$

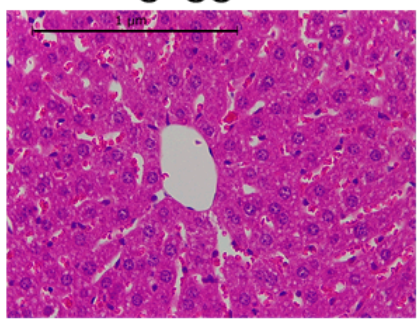

$\mathrm{db} / \mathrm{db}+\mathrm{LYT}$

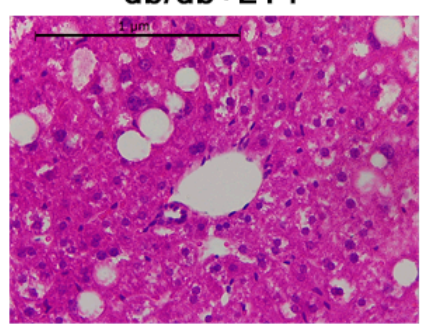

B.

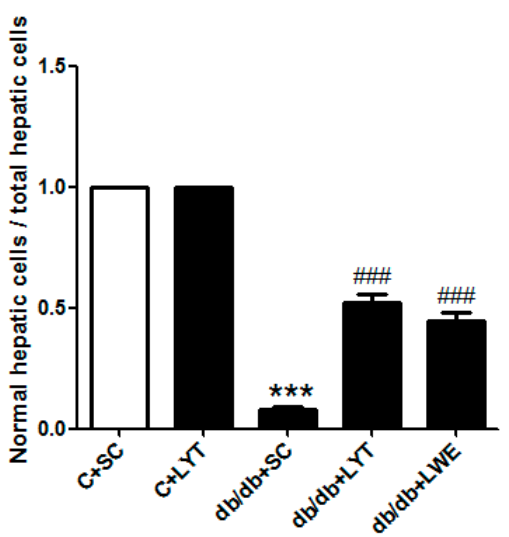

C+LYT

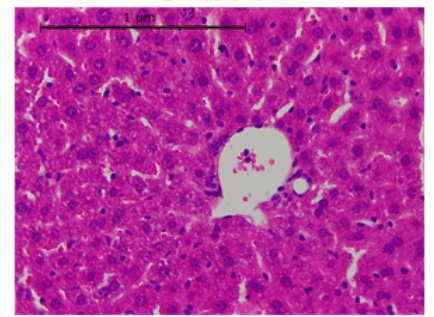

$d b / d b+L W E$

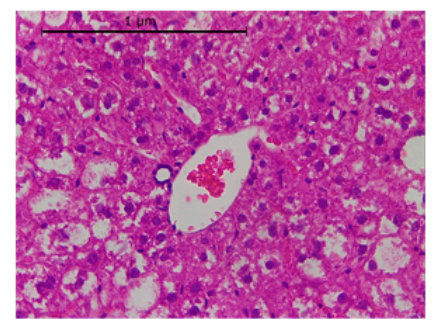

C.

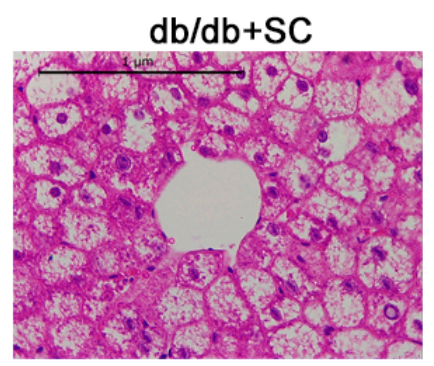

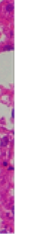 \\ (1)}
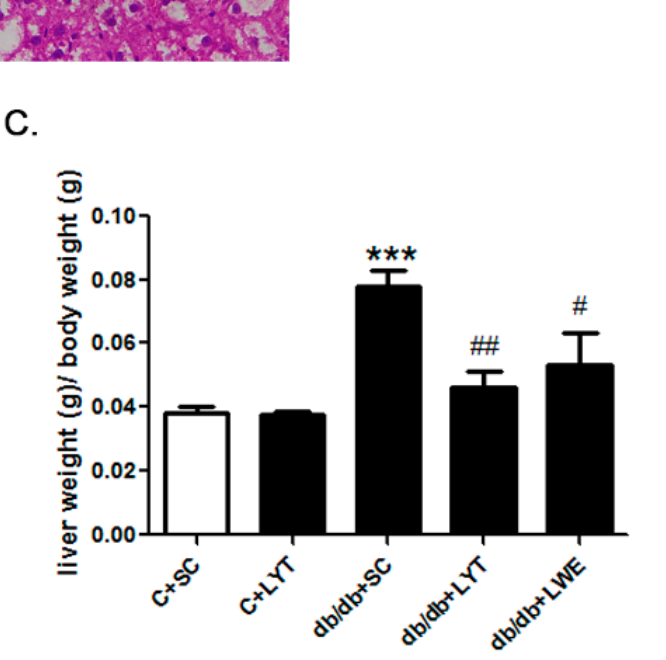

Figure 4. LYT and LWE diets attenuate hepatic steatosis and reduce liver-to-body weight ratio in $\mathrm{db} / \mathrm{db}$ mice. Liver hematoxylin-eosin HE staining (A); normal hepatic cells to total liver cell ratio (5 field of view were randomly selected from each tissue sections for statistics (B); and liver-to-body weight ratio (C). Scale bars are equal to $1 \mu \mathrm{m}$. Values are means $\pm \mathrm{SE}(n=4-6)$. ${ }^{* * *} p<0.001$ when compared with the $\mathrm{C}+\mathrm{SC}$ group; $\# p<0.05$; \#\# $p<0.01$; \#\# $p<0.001$ when compared with the $\mathrm{db} / \mathrm{db}+\mathrm{SC}$ group.

\subsection{LYT and LWE Reduced Lipid Accumulation in Liver Tissues via Suppressing the Lipogenesis in db/db Mice}

Our data proved that LYT and LWE dietary supplements played a pivotal role in improving serum lipid profile and protecting fatty liver formation in $\mathrm{db} / \mathrm{db}$ mice. To figure out the underlying mechanism, we measured the mRNA levels of genes related to the lipid metabolism in liver tissue. The hepatic gene expression data showed a significant increase in fatty acid synthase (Fasn), sterol regulatory element-binding transcription factor 1 (Srebf1), and acetyl-CoA carboxylase $\alpha($ Acaca) in $\mathrm{db} / \mathrm{db}$ mice with a standard chow diet when compared with control mice fed a standard chow diet (Figure 5A-C). Acaca, Fasn, and Srebf1 are genes that work in conjunction to regulate lipogenesis $[13,14,28,29]$. However, the level of gene expression of Acaca, Fasn, and Srebf1 was significantly decreased in db/db mice fed with LYT when compared with $\mathrm{db} / \mathrm{db}$ mice fed a standard chow diet. In addition, no greater difference was observed in the level of these lipogenesis genes between the $\mathrm{db} / \mathrm{db}$ mice fed with LWE and a standard chow diet (Figure 5A-C). 

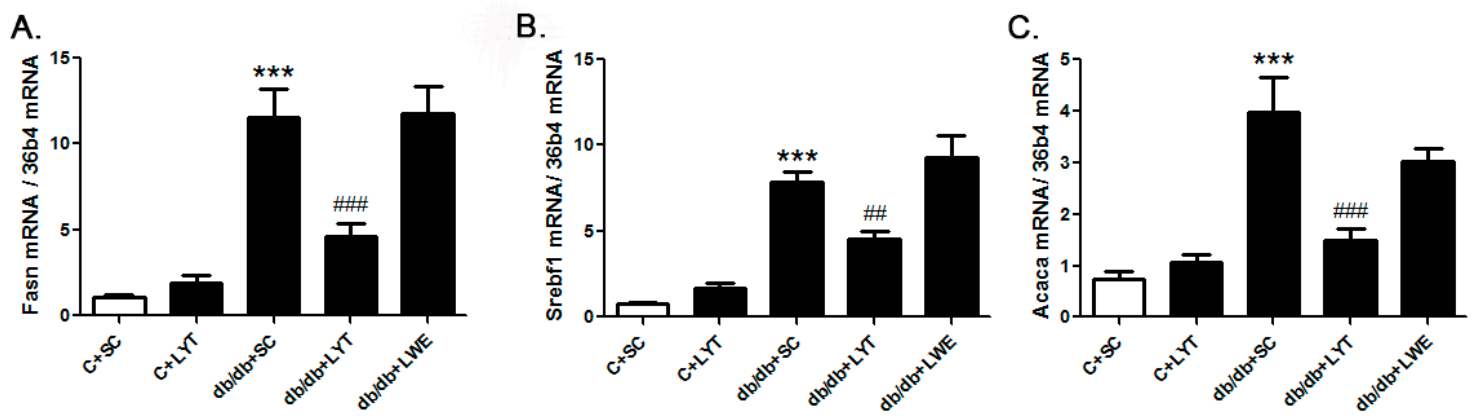

Figure 5. LYT diet decreases hepatic lipogenic gene expression in $\mathrm{db} / \mathrm{db}$ mice. Fasn (A); Sebf1 (B); and Acaca $(\mathbf{C})$. Values are means \pm SE $(n=4-6) .{ }^{* * *} p<0.001$ when compared with the C + SC group; \#\# $p<0.01$; \#\#\# $p<0.001$ when compared with the $\mathrm{db} / \mathrm{db}+\mathrm{SC}$ group.

As the $\mathrm{db} / \mathrm{db}$ mice supplemented with the LYE diet showed the significant downregulation of genes mediating lipogenesis, we further analyzed the protein expression levels of FAS and SREBP-1 between the five groups of mice. In the $\mathrm{db} / \mathrm{db}$ mice fed a standard chow diet, the expression level of FAS and SREBP-1 was significantly higher than that in the control mice fed a standard chow diet, which meant that lipid synthesis in the liver was significantly accelerated in $\mathrm{db} / \mathrm{db}$ mice when compared to control mice. However, the $\mathrm{db} / \mathrm{db}$ mice fed LYT and LWE showed a significant decrease in the protein expression level of FAS and SREBP-1 in contrast to the $\mathrm{db} / \mathrm{db}$ mice fed a standard chow diet (Figure 6A-D). Therefore, our data suggested that the effects of LYT and LWE on preventing fatty liver formation and improving serum lipid profile in $\mathrm{db} / \mathrm{db}$ mice after 10 weeks of dietary supplement might be due to the suppression of hepatic lipogenesis.
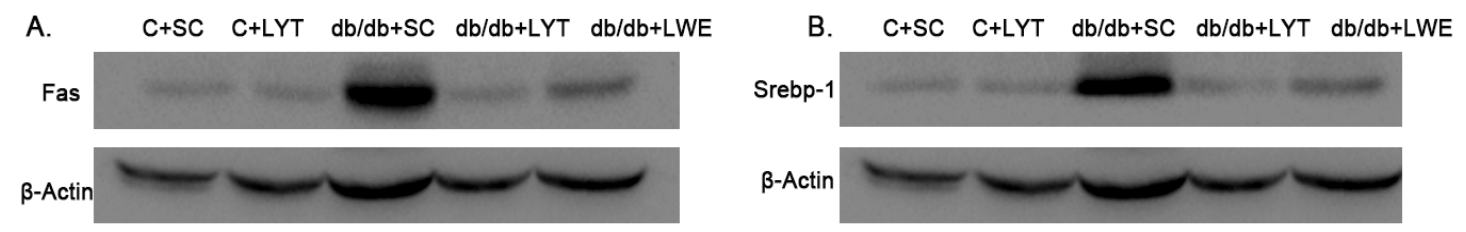

C.

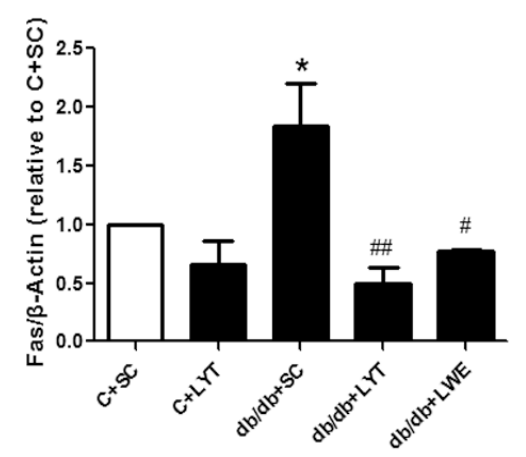

D.

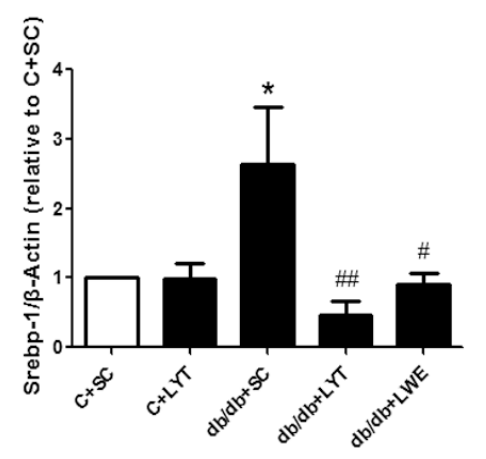

Figure 6. LYT and LWE diets decreased hepatic FAS and SREBP-1 protein expression in $\mathrm{db} / \mathrm{db}$ mice. Representative figure (A) and summarized data (C) for FAS; representative figure (B) and summarized data (D) for SREBP-1. Values are means $\pm \mathrm{SE}(n=4-6)$. ${ }^{*} p<0.05$ when compared with the $\mathrm{C}+\mathrm{SC}$ group; $\# p<0.05 ; \#$; $p<0.01$ when compared with the $\mathrm{db} / \mathrm{db}+\mathrm{SC}$ group.

Interestingly, we found that there was no upregulation of predominant lipolysis genes such as the adiponectin receptor protein 2 (Adipor2), carnitine palmitoyltransferase $1 \mathrm{~A}(C p t 1 a)$, peroxisome proliferator-activated receptor alpha (Ppar $)$, and peroxisome proliferator-activated receptor gamma (Ppar $\gamma$ ) in the livers of $\mathrm{db} / \mathrm{db}$ mice fed with LYT and LWE when compared to the $\mathrm{db} / \mathrm{db}$ mice fed a standard chow diet (Figure 7A-D). 

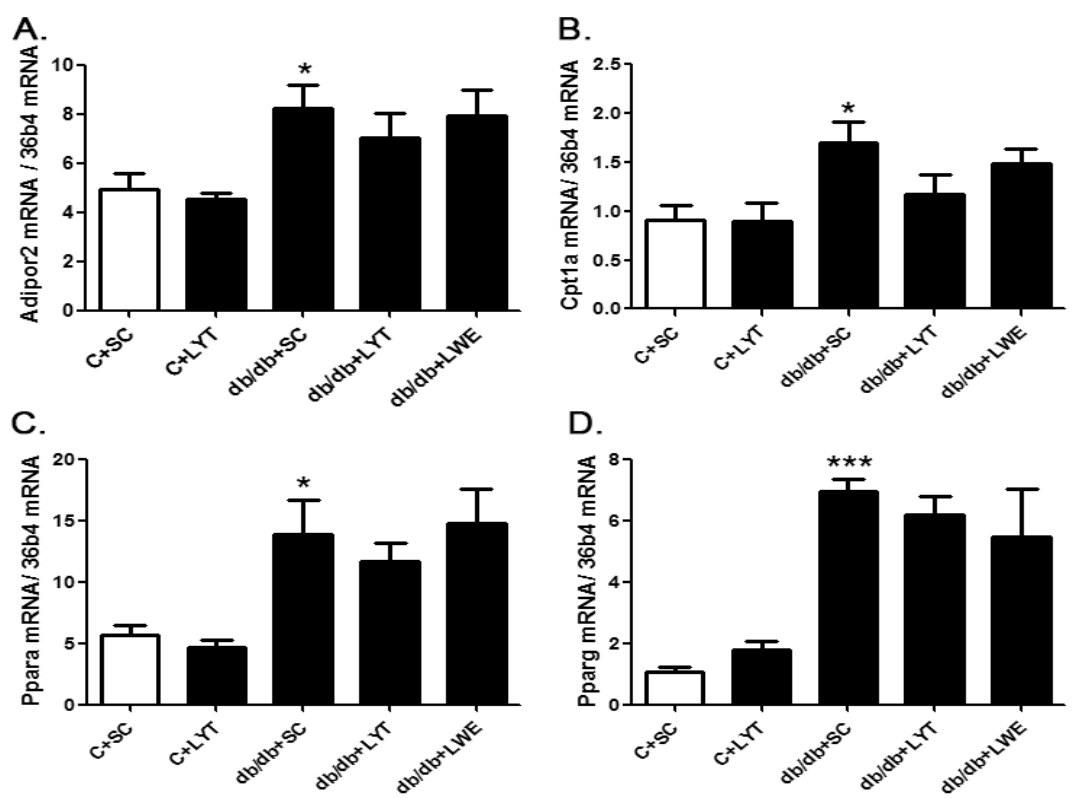

Figure 7. The mRNA expression of genes involved in lipolysis in the liver of control and $\mathrm{db} / \mathrm{db}$ mice

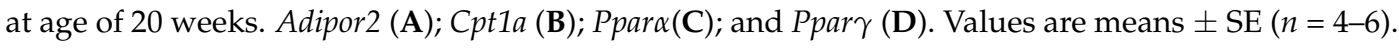
${ }^{*} p<0.05 ;{ }^{* *} p<0.001$ when compared with the $\mathrm{C}+\mathrm{SC}$ group.

\subsection{LYT Improved the Hepatic Glycometabolism in $d b / d b$ Mice}

The hepatic glucokinase (GCK) and glucokinase regulatory protein (GCKR) play key roles in glucose homeostasis by increasing or decreasing glucose output and uptake during fasting and feeding. To identify the mechanism of LYT diets decreasing blood glucose levels in $\mathrm{db} / \mathrm{db}$ mice, we examined the mRNA expressions of Gsk and Gskr in the liver tissues. The real-time polymerase chain reaction (PCR) data revealed that the expression level of Gck in the $\mathrm{db} / \mathrm{db}+\mathrm{SC}$ mice liver was significantly increased when compared with that of the control mice. Moreover, the Gck expression level in the liver was further increased in the $\mathrm{db} / \mathrm{db}+\mathrm{LYT}$ mice when compared with the $\mathrm{db} / \mathrm{db}+\mathrm{SC}$ mice (Figure 8A). GCKR controls both the activity and intracellular location of glucokinase through binding and moving this key enzyme of glycometabolism [30-33]. Therefore, we also measured the expression of Gckr in the liver among the five groups of mice. Our data showed that the $\mathrm{db} / \mathrm{db}+\mathrm{SC}$ mice showed an increased level of Gckr mRNA expression in contrast to the control mice, and Gckr expression showed a significant reduction in $\mathrm{db} / \mathrm{db}$ mice fed LYT when compared to the $\mathrm{db} / \mathrm{db}$ mice fed a standard chow diet (Figure 8B). However, the $\mathrm{db} / \mathrm{db}$ mice fed LWE saw no increase in Gck or any decrease in Gckr expression when compared to the $\mathrm{db} / \mathrm{db}$ mice fed a standard chow diet. These results potentially validated the antagonism between Gck and Gckr.

A.

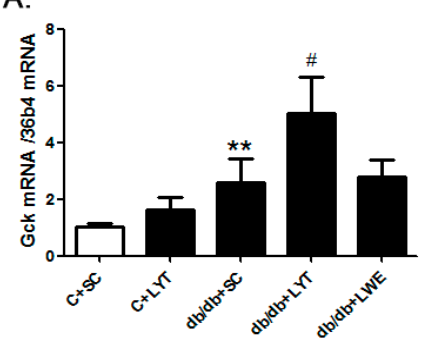

B.

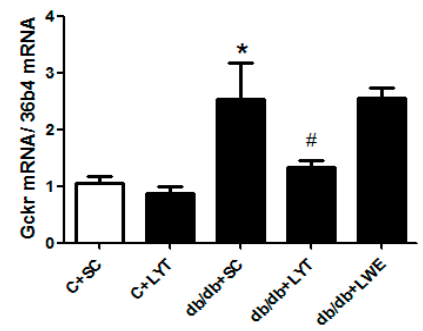

Figure 8. The mRNA expression of Gck (A) and $G c k r(B)$ in the liver of the control and $\mathrm{db} / \mathrm{db}$ mice at 20 weeks old. Values are means $\pm \mathrm{SE}(n=4-6) .{ }^{*} p<0.05 ;{ }^{* *} p<0.01$ when compared with the $\mathrm{C}+\mathrm{SC}$ group; $\# p<0.05$ when compared with the $\mathrm{db} / \mathrm{db}+\mathrm{SC}$ group. 


\section{Discussion}

It is demonstrated for the first time here that large yellow tea is a potential natural health product that attenuates nonalcoholic fatty liver and symptoms of T2D in $\mathrm{db} / \mathrm{db}$ mice including hyperlipidemia and hyperglycemia. Quantitative analysis of the total catechins provided a record of ECGC having the highest level of presence in both LYT and LWE than other catechins subjected to quantification. As many previous studies have investigated the health benefits of pure EGCG, we designed our experiment to keep almost the same concentration of EGCG in both the LYT and LWE diet. If there were any deferent phenotypes between the $\mathrm{db} / \mathrm{db}+\mathrm{LYT}$ and $\mathrm{db} / \mathrm{db}+\mathrm{LWE}$ group mice, we could speculate that the phenotypes were effects of the other catechins or even other functional components rather than EGCG. Considering the fact that people consume whole tea as a beverage or food supplements, it was important to investigate the health benefits of tea powder and water extract. In this experiment, a 5\% LYT diet was used to feed mice, corresponding to the $20 \mathrm{~g}$ daily tea consumption of human [22]. Twenty grams of tea is approximately equal to drinking five cups of tea. This is a reasonable daily amount for regular tea consumers.

It has been reported that teas and their extracts, especially green tea and black tea, have an effect on losing weight in diet-induced obesity and diabetic rodent models [34,35], which was further confirmed in human populations [36,37]. However, the beneficial effect of large yellow tea on losing weight in $\mathrm{db} / \mathrm{db}$ mice has yet to be reported. $\mathrm{db} / \mathrm{db}$ mice are characterized by polydipsia, polyphagia, obesity, and weight loss at later stages concerned with carbohydrate and lipid metabolic disorder [13,38]. In our research, the $\mathrm{db} / \mathrm{db}$ mice showed the phenotype characteristic of excessive eating and drinking as well as obesity, which was not significantly recorded in control mice since the age of 10 weeks (Figure $1 \mathrm{~A}-\mathrm{G}$ ). However, the $\mathrm{db} / \mathrm{db}$ mice fed LYT and LWE showed significantly decreased food consumption and water intake during the entire experimental period. These data suggest that dietary supplements of LYT and LWE efficiently improved diabetic syndrome of $\mathrm{db} / \mathrm{db}$ mice. The $\mathrm{db} / \mathrm{db}+\mathrm{SC}$ group of mice gradually gained weight until 14 weeks and then steadily lost weight from 14 weeks to the end of the experiment at 20 weeks due to the development of the T2D complication. However, the $\mathrm{db} / \mathrm{db}$ mice fed with LYT and LWE showed a consistent increase in body weight until the age of 16 weeks (Figure $1 G$ ), then gradually lost weight at a degree less than the $d b / d b+S C$ group mice. Our results indicated that LYT and LWE diets could delay the development of diabetic complications in $\mathrm{db} / \mathrm{db}$ mice.

The liver is a key metabolic organ that governs glucose and lipid metabolism and plays important roles in the balance of energy $[39,40]$. Dysregulation of lipid metabolism leads to hepatic damage, and even causes severe liver diseases [41]. Hyperglycemia and hyperlipidemia are important phenotypes of metabolic syndrome in $\mathrm{db} / \mathrm{db}$ mice $[13,38]$. It has been reported that green tea as well as black tea decreased lipid accumulation via increasing lipolysis and suppressing lipogenesis in the liver of T2D rodent models [34,35]. In our research, the mRNA expression levels of Acaca, Fasn and Srebf1 in liver tissues were significantly increased in $\mathrm{db} / \mathrm{db}$ mice fed a standard chow diet when compared with the control mice. Acaca, Fasn, and Srebf1 were all involved in lipid synthesis, which indicated increased lipogenesis in the $\mathrm{db} / \mathrm{db}+\mathrm{SC}$ group of mice (Figure $5 \mathrm{~A}-\mathrm{C}$ ). However, the mRNA expression levels of Acaca, Fasn, and Srebf1 in the livers of $\mathrm{db} / \mathrm{db}$ mice treated with LYT were significantly attenuated when compared to $\mathrm{db} / \mathrm{db}$ mice fed a standard chow diet at 20 weeks old. In addition, Western blot results showed that the protein expression levels of FAS and SREBP1 were also dramatically decreased in the liver tissues of $\mathrm{db} / \mathrm{db}$ mice fed with LYT and LWE when compared to that of $\mathrm{db} / \mathrm{db}$ mice fed a standard chow diet. Additionally, FAS or SREBP1 is a key enzyme or a transcriptional factor in regulating lipid and glucose metabolism. These results demonstrated that LYT and LWE dietary supplements regulated the glucose and lipid metabolism in $\mathrm{db} / \mathrm{db}$ mice by decreasing the FAS and SREBP1 expression. Furthermore, this set of data was consistent with the decreased levels of TG, LDL-C, and TC in the serum of $\mathrm{db} / \mathrm{db}$ mice fed with LYT (Figure 2A-C). In contrast, our data indicated that the mRNA levels of main lipolysis genes, Adipor2, Cpt1a, Ppard, and Ppar $\gamma$ were not altered in the liver of $\mathrm{db} / \mathrm{db}$ mice fed with LYT and LWE when compared to $\mathrm{db} / \mathrm{db}$ mice fed a standard chow diet 
(Figure 7A-D). Put together, our data suggested that dietary supplements of LYT or LWE decreased lipid accumulation and that the prevention of fatty liver formation might be involved in suppressing lipogenesis rather than increasing lipolysis. It is possible that the downregulation of Srebf1 and its target gene Fasn catalyzes the downregulation of Acaca in fatty acid synthesis and that this potential molecule contributes to the reduction in de novo lipogenesis [42].

At the age of 10 weeks, the $\mathrm{db} / \mathrm{db}+\mathrm{SC}$ mice showed a significant increase of blood glucose level when compared to the $\mathrm{C}+\mathrm{SC}$ mice $(p<0.001)$. Surprisingly, the blood glucose level was significantly decreased to a level very close to normal glucose levels in $\mathrm{db} / \mathrm{db}$ mice fed with LYT from 14 to 20 weeks old (Figure $3 \mathrm{~A}$ ). In addition, $\mathrm{db} / \mathrm{db}$ mice fed with LYT significantly raised glucose tolerance at the age of 20 weeks (Figure 3B). This result is very important as the dietary supplement of LYT had a very strong effect on decreasing blood glucose in the $\mathrm{T} 2 \mathrm{D} \mathrm{db} / \mathrm{db}$ mice, while the dietary supplement of LWE significantly decreased the blood glucose level of $\mathrm{db} / \mathrm{db}$ mice for only the first two weeks of treatment (12-14 weeks old), and blood glucose then gradually increased from 14 to 16 weeks and stayed at approximately $300 \mathrm{mg} / \mathrm{dL}$ until the end of the experiment (20 weeks). What we found here was that a dietary supplement of large yellow tea powder was better able to decrease blood glucose than the water extract supplement in $\mathrm{db} / \mathrm{db}$ mice.

We further investigated the mechanism of this effect. GCKR, a protein highly expressed in liver cells, plays a crucial role in the inhibition of GCK activity and thus accordingly regulates glucose metabolism in T2D rodent models. Previous studies have reported that GCK activity is decreased in T2D [30-33]. At the age of 20 weeks, we found that the mRNA expression level of $G c k r$ in $\mathrm{db} / \mathrm{db}$ mice was higher than that in the control mice (Figure 8B), which suggested that $\mathrm{db} / \mathrm{db}$ mice developed a glucose metabolism disorder by increasing the expression of GCKR and further decreasing the activity of GCK. This result is consistent with the results reported previously [43-45]. As expected, when compared with the $\mathrm{db} / \mathrm{db}$ mice fed a standard chow diet, the mRNA expression level of Gckr in the liver of $\mathrm{db} / \mathrm{db}$ mice fed the LYT diet was significantly decreased. Accordingly, the mRNA expression level of Gck showed obvious upregulation in the $\mathrm{db} / \mathrm{db}$ mice fed LYT (Figure 8A). These data suggested that the dietary supplement of large yellow tea powder may regulate glucose metabolism in T2D $\mathrm{db} / \mathrm{db}$ mice by accordingly decreasing the expression of GCKR and increasing the expression of GCK in the liver. However, there were no significant differences in the mRNA expressions of Gckr and Gck between the $\mathrm{db} / \mathrm{db}+\mathrm{SC}$ mice and $\mathrm{db} / \mathrm{db}+$ LWE mice at the age of 20 weeks. This may be $\mathrm{a}$ reason why the water extract of large yellow tea had less effect on reducing blood glucose levels and improving glucose tolerance in $\mathrm{db} / \mathrm{db}$ mice.

Overweight, obesity, and diabetes are emerging as major global health issues. If tea could prevent or delay the development of these diseases, the public health implications would be tremendous [17]. So far, most of the beneficial effects of tea are believed to be attributed to the polyphenols in the tea. Although there have been many published studies, the exact functional components and molecular mechanisms are still not fully understood. Yellow tea, as well as green tea and white tea, contain characteristic polyphenolic compounds known as catechins, and EGCG is the major form of tea catechin [46]. Therefore, previous research has mainly focused on EGCG inhibiting obesity, metabolic syndrome in $\mathrm{db} / \mathrm{db}$ mice [21], and high-fat-diet-fed mice [46-48]. Similar results were also observed using black tea extract (BTE) [34] and green tea extract (GTE) [49]. To the best of our knowledge, this is the first work to comparatively investigate the effect of dietary supplements of large yellow tea powder and its water extract on metabolic syndrome, serum lipid profile, and hepatic steatosis in $\mathrm{db} / \mathrm{db}$ mice. Most of the data generated by this study have shown that dietary supplement of large yellow tea powder has more profound protective effects than its water extract in metabolic syndrome, especially in regulating glucose metabolism in the middle stage of T2D in $\mathrm{db} / \mathrm{db}$ mice. As stated previously, we designed our study to keep almost the same concentration of EGCG in the large yellow tea powder diet and its water extract diet. Our results suggested that the other catechins or even other chemical components rather than EGCG may play important roles in alleviating metabolic syndrome, especially in regulating glucose metabolism in $\mathrm{db} / \mathrm{db}$ mice. The water extract of large yellow tea contains only 
water-soluble components, while large yellow tea contains not only water-soluble substances, but also various fat-soluble substances $[16,17]$. Therefore, we hypothesize that a range of substances not extracted by water in large yellow tea may contribute the principal effects of decreasing blood glucose and alleviating metabolic syndrome in $\mathrm{db} / \mathrm{db}$ mice. These exact functional components need further investigation.

\section{Materials and Methods}

\subsection{The Extract of Large Yellow Tea}

The large yellow tea purchased from Bao Er Zhong Xiu Tea Industry Co., Ltd. (Huoshan, Anhui, China) was extracted with pure water at $100{ }^{\circ} \mathrm{C}$ (the ratio of tea powder to pure water was 1:20), for $20 \mathrm{~min}$, then extraction was assisted by ultrasonic (KQ-500DE Shumei, Kunshan, China) in a water bath for $30 \mathrm{~min}$ at $75{ }^{\circ} \mathrm{C}$. The resulting water extract of large yellow tea was further filtered and subjected to concentration using a rotary evaporator (IKA ${ }^{\circledR}$ HB 10, Staufen, German). Finally, the concentrated extraction was freeze-dried to form a solid powder in order to add to the AIN93 standard diet for experiment.

\subsection{Analysis of Major Chemical Components of Large Yellow Tea and Its Water Extract}

The catechins, theanine, and caffeine were analyzed on a Waters High Performance Liquid Chromatography (HPLC) system supported with a Waters 600 controller and Waters 2489 UV/Visible Detector (280 nm). Chromatographic separation was performed on a Phenomenex Gemini C18 column. The column temperature was set at $25{ }^{\circ} \mathrm{C}$. The injection volume of sample was $5 \mu \mathrm{L}$, the elution rate was $1 \mathrm{~mL} / \mathrm{min}$, and the detection wavelength was set at $278 \mathrm{~nm}$. The mobile phase consisted of mobile phase A (deionized water with $0.17 \%$ acetic acid) and mobile phase B (100\% acetonitrile). The linear gradient at a flow rate of $1.0 \mathrm{~mL} / \mathrm{min}$ was set as follows: mobile phase B from $8-28.4 \%(v / v)$ in $30 \mathrm{~min}$ was initiated, from $28.4-100 \%(v / v)$ for $8 \mathrm{~min}$, and from $100-8 \%(v / v)$ for another $10 \mathrm{~min}$.

\subsection{Animal Experiments}

C57BLKsJ-db/ + mice (control mice, $n=12)$ and male C57BLKsJ-db/db (db/db mice, $n=18)$ were purchased from the National Resource Center of Model Mice (NRCMM, Nanjing, China) and allowed to acclimate to the environment of the specific pathogen free (SPF) laboratory animal center at Anhui Agricultural University, which was controlled with a constant temperature $\left(22 \pm 1^{\circ} \mathrm{C}\right)$ and humidity $(50 \pm 5 \%)$ under a 12:12 h light-dark cycle falls on 8:00 a.m. to 8:00 p.m. All animals were housed in cages and had free access to water and diet. Animals were fed normally until 10 weeks old, and then control mice were randomly divided into two groups, while $\mathrm{db} / \mathrm{db}$ mice were divided into three groups fed with different diets. The detailed group assignments for the mice are described in Figure 1. All animal procedures were approved by the Institutional Animal Care and Use Committee of the Anhui Agricultural University (ethical approval code: AHAU 2016-007).

The standard AIN93 diet (SC), SC containing 5\% of the large yellow tea powder (LYT), and SC containing $1.5 \%$ of the large yellow tea water extract (LWE) were purchased from Trophic Animal Feed High-Tech Co., Ltd. (Nantong, China). The water consumption and food intake were monitored daily, fasting blood glucose level, and body weights were measured at weekly intervals. Blood was obtained from the tail, and the glucose concentrations were measured using Nova StatStrip Xpresst ${ }^{\mathrm{M}}$ Glucose CR Meter (Nova Biomedical, Waltham, UK) with Nova StatStrip Xpresst ${ }^{\mathrm{M}}$ Glu-test Strips (Nova Biomedical, Waltham, UK).

At the end of the 10 week dietary treatments, the mice fasted for $12 \mathrm{~h}$, were anesthetized via injection with $4 \%$ chloral hydrate $(10 \mathrm{~mL} / \mathrm{kg}$, i.p.), and were then sacrificed after the peripheral blood collection from the ophthalmic vein. Serum was obtained by centrifugation at $3000 \mathrm{rpm} / \mathrm{min}$ for $5 \mathrm{~min}$ at $4{ }^{\circ} \mathrm{C}$ then stored at $-80{ }^{\circ} \mathrm{C}$. The levels of triglyceride (TG), low-density lipoprotein cholesterol (LDL-C), high-density lipoprotein cholesterol (HDL-C), and total cholesterol (TC) in the serum were 
measured using micro test kits from Nanjing Jiancheng Bioengineering Institute (Nanjing, Jiangsu, China). Liver weights were measured on a scale to determine liver mass. All other tissue samples were harvested for further biochemical, molecular, and immunostaining analyses. Small pieces of the liver tissues were preserved in RNAlater solution for gene expression experiments, and the other small pieces of the liver tissues were fixed in formaldehyde solution from ZHANYUN (Wuxi, Jiangsu, China) at $4{ }^{\circ} \mathrm{C}$ preserved for histological experiment, and the rest of the liver tissues were immediately liquid nitrogen frozen before being stored at $-80^{\circ} \mathrm{C}$ for the protein expression experiment.

\subsection{Glucose Tolerance Test}

Glucose tolerance test (GTT) were performed at the age of 18 weeks. The fasting mice were given an intraperitoneal injection of glucose (D-(+)-Glucose (SIGMA, St. Louis, MO, USA) at the dosage of $1.5 \mathrm{~g} / \mathrm{kg}$ body weight and the blood samples were collected from tail veins of the mice and glucose levels were measured at 0,30, 60, 90, and $120 \mathrm{~min}$ before and after injection [50].

\subsection{Hematoxylin-Eosin Staining}

All of the liver tissues for the histological chemistry experiment were fixed in $10 \%$ neutrally buffered formalin solution at room temperature, dehydrated, and embedded in paraffin (Paraplast Tissue Embedding Medium, LEICA, Buffalo Grove, IL, USA) using a modular tissue embedding system (LEICA EG1150 H, Buffalo Grove, IL, USA). Hematoxylin-eosin (HE) staining was carried out on $5 \mu \mathrm{m}$ sections using a fully automated rotary microtome (LEICA RM2255, Nussloch, Germany) and mounted onto positive charged slides (Adhesion Microscope Slides, CITOGLAS, Shanghai, China). HE staining of the liver paraffin sections was performed using an HE staining kit (Boster Biological Technology Company, Pleasanton, California, USA) and was pictured by microscope (LEICA DM500, Wetzlar, Germany) with a supporting camera (LEICA ICC50 W, Wetzlar, Germany). The hepatic adipose infiltration cells were counted manually using ImageJ software (Version 1.51q).

\subsection{Real-Time Polymerase Chain Reaction PCR}

Total RNA was extracted from the liver tissues, which were fixed in RNA stabilization solution (Thermo Fisher Scientific, Waltham, Massachusetts, USA) at $-80{ }^{\circ} \mathrm{C}$, and was isolated using RNA isolator (Vazyme Biotech Co., Ltd., Nanjing, Jiangsu, China) as per the manufacturer's instructions. Reverse transcription was performed using HiScript ${ }^{\circledR}$ II 1st Strand cDNA Synthesis kit (Vazyme Biotech Co., Ltd., Nanjing, China), and reverse transcriotion-polymerase chain reaction (RT-PCR) was performed using the Bio-Rad CFX System and AceQ qPCR SYBR Green Master Mix kit (Vazyme Biotech Co., Ltd., Nanjing, China). Real-time PCR was performed following the method described previously in [51-54]. Primer sequences were designed for mice and listed in Table 2.

Table 2. Primer sequences used for RT-PCR gene expression experiment.

\begin{tabular}{|c|c|c|}
\hline \multirow[b]{2}{*}{ Gene } & \multicolumn{2}{|c|}{ Primer Sequences } \\
\hline & Forward $\left(5^{\prime}-3^{\prime}\right)$ & Reverse $\left(5^{\prime}-3^{\prime}\right)$ \\
\hline $36 b 4$ & CCC TGA AGT GCT CGA CAT CA & TGC GGA CAC CCT CCA GAA \\
\hline Fasn & CGT GTG ACC GCC ATC TAT ATC G & TGA GGT TGC TGT CGT CTG TAG TCT T \\
\hline Srebf1 & AGT CCA GCC TTT GAG GAT AGC C & CCG TAG CAT CAG AGG GAG TGA G \\
\hline Acaca & AGG AGG GAA AGG GAT CAG AAA AG & CAG AGC AGT CAC GAC CAA ACA AA \\
\hline Adipor2 & CCT TTC GGG CCT GTT TTA AGA & GAG TGG CAG TAC ACC GTG TG \\
\hline Cpt1a & CTT CAA AAA CAG CAA GAT AGG CAT A & TTA CAG TGT CCA TCC TCT GAG TAG C \\
\hline Ppara & TAC GCT CCC GAC CCA TCT TTA & GAC TCC TTG GCA GTG TCC ATC T \\
\hline Pparg & GAA AGA CAA CGG ACA AAT CAC CAT & CGG CTT CTA CGG ATC GAA ACT G \\
\hline Gck & AGA CGA AAC ACC AGA TGT ATT CC & GAA GCC CTT GGT CCA GTT GAG \\
\hline Gckr & GAC CCG GAA CTT GGA CAA AG & AAT GCC ATA CGA CCA GAG GTG \\
\hline
\end{tabular}




\subsection{Western Blot Analysis}

Western blot was performed following the method described previously in [52-54]. In brief, the frozen liver tissues were homogenized using a $2 \times$ SDS buffer. Equal amounts of denatured proteins were separated by SDS-PAGE gels and transferred to nitrocellulose membranes. The membranes were blocked with 5\% skimmed milk powder in PBS-T solution for $1 \mathrm{~h}$ and were incubated with fatty acid synthase (FAS) (Santa Cruz Biotechnology, Santa Cruz, CA, USA), sterol regulatory element-binding protein-1 (SREBP-1) (Santa Cruz Biotechnology, Santa Cruz, CA, USA), and $\beta$-Actin (Proteintech ${ }^{\mathrm{TM}}$, Wuhan, Hubei, China) at $4{ }^{\circ} \mathrm{C}$ overnight, then incubated with appropriate secondary antibodies (Proteintech ${ }^{\mathrm{TM}}$, Wuhan, Hubei, China) for $1 \mathrm{~h}$ at room temperature. Protein bands were detected by enhanced chemiluminescent (ECL) reagent (Vazyme Biotech Co., Ltd., Nanjing, China) and analyzed using the ChemicDoc ${ }^{\mathrm{TM}}$ MP Imaging System (Bio-Rad, Hercules, CA, USA) with supporting system (ImageLab., Bio-Rad, Hercules, CA, USA).

\subsection{Statistical Analysis}

The results were expressed as mean \pm SEM. Comparisons between the two groups were performed with an unpaired 2-tailed Student's $t$-test, and multiple group comparisons were performed by one-way ANOVA followed by Tukey's test. $p<0.05$ was used to consider statistical significance.

Acknowledgments: This research was funded by the National Sciences Foundation of China (Grant Number 31571207) and a grant for Nutrition and Quality \& Safety of Agricultural Products from the Anhui Province Talent Team Program to Z.X.

Author Contributions: Y.T. was responsible for performing the experiments, collecting data, and preparing the manuscript draft; D.L. conceived the research goals and oversaw the implementation and editing of the manuscript; P.G. was responsible for analyzing the data and editing the manuscript; N.X. was involved in the animal study and editing the manuscript; Z.X. was responsible for conceiving the research goals and experimental design, analyzing data, writing, and editing the manuscript. All authors read and approved the final manuscript. Y.T. and D.L. contributed equally to this work.

Conflicts of Interest: The authors declare no conflict of interest. The founding sponsors had no role in the design of the study; in the collection, analyses, or interpretation of data; in the writing of the manuscript; or in the decision to publish the results.

\section{References}

1. Dandona, P.; Aljada, A.; Chaudhuri, A.; Mohanty, P.; Garg, R. Metabolic syndrome, a comprehensive perspective based on interactions between obesity, diabetes, and inflammation. Circulation 2005, 111, 1448-1454. [CrossRef] [PubMed]

2. Forbes, J.M.; Fotheringham, A.K. Vascular complications in diabetes: Old messages, new thoughts. Diabetologia 2017. [CrossRef] [PubMed]

3. Alberti, K.G.; Zimmet, P.; Shaw, J. The metabolic syndrome-a new worldwide definition. Lancet 2005, 366, 1059-1062. [CrossRef]

4. Schulman, R.C.; Mechanick, J.L. Metabolic and nutrition support in the chronic cirtical illness syndrome. Respir. Care 2012, 57, 958-978. [CrossRef] [PubMed]

5. Wilson, P.W.; D'Agostino, R.B.; Parise, H.; Sullivan, L.; Meigs, J.B. Metabolic syndrome as a precursor of cardiovascular disease and type 2 diabetes mellitus. Circulation 2005, 112, 3066-3072. [CrossRef] [PubMed]

6. Oda, E. Metabolic syndrome: Its history, mechanisms, and limitations. Acta Diabetol. 2012, 49, 89-95. [CrossRef] [PubMed]

7. Cryer, M.J.; Horani, T.; DiPette, D.J. Diabetes and Hypertension: A Comparative Review of Current Guidelines. J. Clin. Hypertens. 2016, 18, 95-100. [CrossRef] [PubMed]

8. Vague, J. The degree of masculine differentiation of obesities: A factor determining predisposition to diabetes, atherosclerosis, gout, and uric calculous disease. Am. J. Clin. Nutr. 1956, 4, 20-34. [CrossRef] [PubMed]

9. Reaven, G.M. Role of insulin resistance in human disease (syndrome X): An expanded definition. Annu. Rev. Med. 1993, 44, 121-131. [CrossRef] [PubMed] 
10. Samson, S.L.; Garber, A.J. Metabolic syndrome. Endocrinol. Metab. Clin. N. Am. 2014, 43, 1-23. [CrossRef] [PubMed]

11. Engin, A. The Definition and Prevalence of Obesity and Metabolic Syndrome. Adv. Exp. Med. Biol. 2017, 960, 1-17. [CrossRef] [PubMed]

12. Sandouk, Z.; Lansang, M.C. Diabetes with obesity-Is there an ideal diet? Clevel. Clin. J. Med. 2017, 84, S4-S14. [CrossRef] [PubMed]

13. Su, W.; Guo, Z.; Randall, D.C.; Cassis, L.; Brown, D.R.; Gong, M.C. Hypertension and disrupted blood pressure circadian rhythm in type 2 diabetic db/db mice. Am. J. Physiol. Heart Circ. Physiol. 2008, 295, 1634-1641. [CrossRef] [PubMed]

14. Lee, Y.; Berglund, E.D.; Yu, X.; Wang, M.Y.; Evans, M.R.; Scherer, P.E.; Holland, W.L.; Charron, M.J.; Roth, M.G.; Unger, R.H. Hyperglycemia in rodent models of type 2 diabetes requires insulin-resistant alpha cells. Proc. Natl. Acad. Sci. USA 2014, 111, 13217-13222. [CrossRef] [PubMed]

15. Sharma, K.; McCue, P.; Dunn, S.R. Diabetic kidney disease in the db/db mouse. Am. J. Physiol. Ren. Physiol. 2003, 284, 1138-1144. [CrossRef] [PubMed]

16. Ning, J.; Li, D.; Luo, X.; Ding, D.; Song, Y.; Zhang, Z.; Wan, X. Stepwise identification of six tea (Camellia sinensis (L.) categories based on catechins, caffeine, and theanine contents combined with fisher discriminant analysis. Food Anal. Method 2016, 9, 3242-3250. [CrossRef]

17. Yang, C.S.; Zhang, J.; Zhang, L.; Huang, J.; Wang, Y. Mechanisms of body weight reduction and metabolic syndrome alleviation by tea. Mol. Nutr. Food Res. 2016, 60, 160-174. [CrossRef] [PubMed]

18. Bogdanski, P.; Suliburska, J.; Szulinska, M.; Stepien, M.; Pupek-Musialik, D.; Jablecka, A. Green tea extract reduces blood pressure, inflammatory biomarkers, and oxidative stress and improves parameters associated with insulin resistance in obese, hypertensive patients. Nutr. Res. 2012, 32, 421-427. [CrossRef] [PubMed]

19. Paradee, A.; Montira, P.; Oratai, T.; Bung-orn, S.; Narong, A.; Bandit, T.; Soontorn, K.; Srisuda, W.; Supat, S.; Pranithi, H. Effectiveness of green tea on weight reduction in obese Thais: A randomized, controlled trail. Physiol. Behav. 2008, 93, 486-491. [CrossRef]

20. Kang, S.J.; Lee, J.E.; Lee, E.K.; Jung, D.H.; Song, C.H.; Park, S.J.; Choi, S.H.; Han, C.H.; Ku, S.K.; Lee, Y.J. Fermentation with Aquilariae Lignum enhances the anti-diabetic activity of green tea in type II diabetic $\mathrm{db} / \mathrm{db}$ mouse. Nutrients 2014, 6, 3536-3571. [CrossRef] [PubMed]

21. Ortsäter, H.; Grankvist, N.; Wolfram, S.; Kuehn, N.; Sjöholm, A. Diet supplementation with green tea extract epigallocatechin gallate prevents progression to glucose intolerance in $\mathrm{db} / \mathrm{db}$ mice. Nutr. Metab. 2012, 9, 11. [CrossRef] [PubMed]

22. Han, M.; Zhao, G.; Wang, Y.; Wang, D.; Sun, F.; Ning, J.; Wan, X.; Zhang, J. Safety and anti-hyperglycemic efficacy of various tea types in mice. Sci. Rep. 2016, 6, 31703. [CrossRef] [PubMed]

23. Stuart, E.C.; Jarvis, R.M.; Rosengren, R.J. In vitro mechanism of action for the cytotoxicity elicited by the combination of epigallocatechingallate and raloxifene in MDA-MB-231 cells. Oncol. Rep. 2010, 24, 779-785. [CrossRef] [PubMed]

24. Isbrucker, R.A.; Edwards, J.A.; Wolz, E.; Davidovich, A.; Bausch, J. Safety studies on epigallocatechingallate (EGCG) preparations. Part 2: Dermal, acute and short-term toxicity studies. Food Chem. Toxicol. 2006, 44, 636-650. [CrossRef] [PubMed]

25. Kucera, O.; Mezera, V.; Moravcova, A.; Endlicher, R.; Lotkova, H.; Drahota, Z.; Cervinkova, Z. In vitro toxicity of epigallocatechingallate in rat liver mitochondria and hepatocytes. Oxid. Med. Cell. Longev. 2015, 2015, 476180. [CrossRef] [PubMed]

26. Kim, K.E.; Jung, Y.; Min, S.; Nam, M.; Heo, R.W.; Jeon, B.T.; Song, D.H.; Yi, C.O.; Jeong, E.A.; Kim, H.; et al. Caloric restriction of $\mathrm{db} / \mathrm{db}$ mice reverts hepatic steatosis and body weight with divergent hepatic metabolism. Sci. Rep. 2016, 6, 30111. [CrossRef] [PubMed]

27. Porcellati, F.; Lucidi, P.; Bolli, G.B.; Fanelli, C.G. Thirty years of research on the dawn phenomenon: Lessons to optimize blood glucose control in diabetes. Diabetes Care 2013, 36, 3860-3862. [CrossRef] [PubMed]

28. Fullerton, M.D.; Galic, S.; Marcinko, K.; Sikkema, S.; Pulinilkunnil, T.; Chen, Z.P.; O’Neill, H.M.; Ford, R.J.; Palanivel, R.; O'Brien, M.; et al. Single phosphorylation sites in Acc1 and Acc2 regulate lipid homeostasis and the insulin-sensitizing effects of metformin. Nat. Med. 2013, 19, 1649-1654. [CrossRef] [PubMed]

29. Geng, F.; Cheng, X.; Wu, X.; Yoo, J.Y.; Cheng, C.; Guo, J.Y.; Mo, X.; Ru, P.; Hurwitz, B.; Kim, S.H.; et al. Inhibition of SOAT1 suppresses glioblastoma growth via blocking SREBP-1-mediated lipogenesis. Clin. Cancer Res. 2016, 22, 5337-5348. [CrossRef] [PubMed] 
30. Hattersley, A.T.; Tooke, J.E. The fetal insulin hypothesis: An alternative explanation of the association of low birth weight with diabetes and vascular disease. Lancet 1999, 353, 1789-1792. [CrossRef]

31. Callejas, D.; Mann, C.J.; Ayuso, E.; Lage, R.; Grifoll, I.; Roca, C.; Andaluz, A.; Ruiz-de, G.R.; Montané, J.; Muñoz, S.; et al. Treatment of diabetes and long-term survival after insulin and glucokinase gene therapy. Diabetes 2013, 62, 1718-1729. [CrossRef] [PubMed]

32. Zelent, B.; Raimondo, A.; Barett, A.; Buettger, C.W.; Chen, P.; Gloyn, A.L.; Matschinsky, F.M. Analysis of the co-operative interaction between the allosterically regulated proteins GK and GKRP using tryptophan fluorescence. Biochem. J. 2014, 459, 551-564. [CrossRef] [PubMed]

33. Lloyd, D.J.; St Jean, D.J., Jr.; Kurzeja, R.J.; Wahl, R.C.; Michelsen, K.; Cupples, R.; Chen, M.; Wu, J.; Sivits, G.; Helmering, J.; et al. Antidiabetic effects of glucokinase regulatory protein small-molecule disruptors. Nature 2013, 504, 437-440. [CrossRef] [PubMed]

34. Uchiyama, S.; Taniguchi, Y.; Saka, A.; Yoshida, A.; Yajima, H. Prevention of diet-induced obesity by dietary black tea polyphenols extract in vitro and in vivo. Nutrition 2011, 27, 287-292. [CrossRef] [PubMed]

35. Bruno, R.S.; Dugan, C.E.; Smyth, J.A.; DiNatale, D.A.; Koo, S.I. Green tea extract protects leptin-deficient, spontaneously obese mice from hepatic steatosis and injury. J. Nutr. 2008, 138, 323-331. [PubMed]

36. Jurgens, T.M.; Whelan, A.M.; Killian, L.; Doucette, S.; Kirk, S.; Foy, E. Green tea for weight loss and weight maintenance in overweight or obese adults. Cochrane Database Syst. Rev. 2012, 12, CD008650. [CrossRef] [PubMed]

37. Hursel, R.; Viechtbauer, W.; Westerterp-Plantenga, M.S. The effects of green tea on weight loss and weight maintenance: A meta-analysis. Int. J. Obes. 2009, 33, 956-961. [CrossRef] [PubMed]

38. Zhao, C.; Qiao, C.; Tang, R.H.; Jiang, J.; Li, J.; Martin, C.B.; Bulaklak, K.; Li, J.; Wang, D.W.; Xiao, X. Overcoming insulin insuffciency by forced follistatin expression in $\beta$-cells of $\mathrm{db} / \mathrm{db}$ mice. Mol. Ther. 2015, 23, 866-874. [CrossRef] [PubMed]

39. Bechmann, L.P.; Hannivoort, R.A.; Gerken, G.; Hotamisligil, G.S.; Trauner, M.; Canbay, A. The interaction of hepatic lipid and glucose metabolism in liver diseases. J. Hepatol. 2012, 56, 952-964. [CrossRef] [PubMed]

40. Marchesini, G.; Petta, S.; Dalle, G.R. Diet, weight loss, and liver health in nonalcoholic fatty liver disease: Pathophysiology, evidence, and practice. Hepatology 2016, 63, 2032-2043. [CrossRef] [PubMed]

41. Lee, S.; Mardinoglu, A.; Zhang, C.; Lee, D.; Nielsen, J. Dysregulated signaling hubs of liver lipid metabolism reveal hepatocellular carcinoma pathogenesis. Nucleic Acids Res. 2016, 44, 5529-5539. [CrossRef] [PubMed]

42. Ameer, F.; Scandiuzzi, L.; Hasnian, S.; Kalbacher, H.; Zaidi, N. De novo lipogenesis in health and disease. Metabolism 2014, 63, 895-902. [CrossRef] [PubMed]

43. Bonetti, S.; Trombetta, M.; Boselli, M.L.; Turrini, F.; Malerba, G.; Trabetti, E.; Pignatti, P.F.; Bonora, E.; Bonadonna, R.C. Variants of GCKR affect both $\beta$-cell and kidney function in patients with newly diagnosed type 2 diabetes: The Verona newly diagnosed type 2 diabetes study 2. Diabetes Care 2011, 34, 1205-1210. [CrossRef] [PubMed]

44. Hu, C.; Zhang, R.; Wang, C.; Yu, W.; Lu, J.; Ma, X.; Wang, J.; Jiang, F.; Tang, S.; Bao, Y.; Xiang, K.; Jia, W. Effects of GCK, GCKR, G6PC2 and MTNR1B variants on glucose metabolism and insulin secretion. PLoS ONE 2010, 5, e11761. [CrossRef] [PubMed]

45. Haeusler, R.A.; Camastra, S.; Astiarraga, B.; Nannipieri, M.; Anselmino, M.; Ferrannini, E. Decreased expression of hepatic glucokinase in type 2 diabetes. Mol. Metab. 2014, 4, 222-226. [CrossRef] [PubMed]

46. Bose, M.; Lambert, J.D.; Ju, J.; Reuhl, K.R.; Shapses, S.A.; Yang, C.S. The major green tea polyphenol, (-)-epigallocatechin-3-gallate, inhibits obesity, metabolic syndrome, and fatty liver disease in high-fat-fed mice. J. Nutr. 2008, 138, 1677-1683. [PubMed]

47. Chen, Y.K.; Cheung, C.; Reuhl, K.R.; Liu, A.B.; Lee, M.J.; Lu, Y.P.; Yang, C.S. Effects of green tea polyphenol (-)-epigallocatechin-3-gallate on newly developed high-fat/Western-style diet-induced obesity and metabolic syndrome in mice. J. Agric. Food Chem. 2011, 59, 11862-11871. [CrossRef] [PubMed]

48. Byu, J.K.; Yoon, B.Y.; Jhun, J.Y.; Oh, H.J.; Kim, E.K.; Min, J.K.; Cho, M.L. Epigallocatechin-3-gallate ameliorates both obesity and autoinflammatory arthritis aggravated by obesity by altering the balance among CD4+ T-cell subsets. Immunol. Lett. 2014, 157, 51-59. [CrossRef]

49. Okuda, M.H.; Zemdegs, J.C.; de Santana, A.A.; Santamarina, A.B.; Moreno, M.F.; Hachui, A.C.; dos Santos, B.; do Nascimento, C.M.; Ribero, E.B.; Oyama, L.M. Green tea extract improves high fat diet-induced hypothalamic inflammation, without affecting the serotoninergic system. J. Nutr. Biochem. 2014, 25, 1084-1089. [CrossRef] [PubMed] 
50. Tian, L.; Zeng, K.; Shao, W.; Yang, B.B.; Fantus, I.G.; Weng, J.; Jin, T. Short-Term Curcumin Gavage Sensitizes Insulin Signaling in Dexamethasone-Treated C57BL/6 Mice. J. Nutr. 2015, 145, 2300-2307. [CrossRef] [PubMed]

51. Xie, Z.; Gong, M.C.; Su, W.; Turk, J.; Guo, Z. Group VIA phospholipase $\mathrm{A}_{2}\left(\mathrm{iPLA}_{2} \beta\right)$ participates in angiotensin II-induced transcriptional up-regulation of regulator of G-protein signaling-2 in vascular smooth muscle cells. J. Biol. Chem. 2007, 282, 25278-25289. [CrossRef] [PubMed]

52. Xie, Z.; Su, W.; Guo, Z.; Pang, H.; Post, S.R.; Gong, M.C. Up-regulation of CPI-17 phosphorylation in diabetic vasculature and high glucose cultured vascular smooth muscle cells. Cardiovasc. Res. 2006, 69, 491-501. [CrossRef] [PubMed]

53. Xie, Z.; Liu, D.; Liu, S.; Calderon, L.; Zhao, G.; Turk, J.; Guo, Z. Identification of a cAMP-response element in the regulator of G-protein signaling-2 (RGS2) promoter as a key Cis-regulatory element for RGS2 transcriptional regulation by angiontensin II in cultured vascular smooth muscles. J. Biol. Chem. 2011, 286, 44646-44658. [CrossRef] [PubMed]

54. Xie, Z.; Su, W.; Liu, S.; Zhao, G.; Esser, K.; Schroder, E.A.; Lefta, M.; Stauss, H.M.; Guo, Z.; Gong, M.C. Smooth-muscle BMAL1 participates in blood pressure circadian rhythm regulation. J. Clin. Investig. 2015, 125, 324-336. [CrossRef] [PubMed]

(C) 2018 by the authors. Licensee MDPI, Basel, Switzerland. This article is an open access article distributed under the terms and conditions of the Creative Commons Attribution (CC BY) license (http:/ / creativecommons.org/licenses/by/4.0/). 